Gut, 1986, 27, 471-474

Leading articles

\title{
Does food affect acute inflammatory bowel disease? The role of parenteral nutrition, elemental and exclusion diets
}

Recommendations concerning nutritional and dietary treatment of inflammatory bowel disease can be bewildering and at times stretch credibility. There are several fairly radical approaches for patients with active disease which are invariably expensive, difficult to implement and largely invalidated by control trials. Each method has enthusiastic protagonists, but none has gained universal acceptance and most clinicians prefer to watch developments from the sidelines with healthy scepticism, tempered by a feeling of insecurity lest they should fail to recognise some important clinical advance. Diseased bowel, nutritional status and diet must surely be inter-related. Attempts to draw together strands of truth from the entangled skein of observations are made difficult because many reports are uncontrolled and contain small numbers of mixed groups of patients with Crohn's disease and ulcerative colitis who have usually been given several treatments simultaneously, so that the effect of nutritional manipulation may be difficult to decipher.

Most of us would be reluctant to adopt wholesale regimes such as total parenteral nutrition, elemental diets, or 'patient tailored' exclusion diets, which are difficult to manage while their benefits remain unconfirmed. We will discuss some of the available evidence for the value of these measures.

Acute ulcerative colitis, sufficiently severe to warrant hospital admission is uncommon, but should medical treatment then fail, surgery with colectomy still carries a high mortality. ${ }^{1}$ In these circumstances any medical measure which may decrease the number of deaths or avert surgery, deserves special consideration. In this issue of Gut a collaborative study from St. Mark's Hospital, London and L'Hopital Charles Nicolle, Rouen has examined the value of 'bowel rest' with parenteral nutrition over seven days, compared with oral diet in patients with severe colitis given $60 \mathrm{mg}$ intravenous prednisolone daily. ${ }^{2}$ Twenty seven had ulcerative colitis of whom 14 required early surgery, with three associated deaths; there was no significant difference in the need for surgery between those given bowel rest (nine of 15) compared with oral diet (five of 12). These findings are similar to those in the only previous controlled study which included 27 patients with severe ulcerative colitis. ${ }^{3}$ Numbers are small, but these two studies suggest that bowel rest with parenteral nutrition does not appear to be valuable in this situation. This should perhaps not come as a surprise, as early surgical attempts to isolate and 'rest' the colon in patients with severe ulcerative colitis were disappointing, ${ }^{4}$ and patients with a retained rectal stump after colectomy often have continuing severe 
proctitis. The severity of the inflammatory disease must determine the outcome and any improvement in nutrition from hyperalimentation is presumably of little consequence during this stormy period.

Acute Crohn's disease on the other hand, has been treated with various dietary measures for which claims of substantial benefit have been made. In Crohn's disease the clinical course is often different from ulcerative colitis, because in addition to the consequences of acutely inflamed bowel, small intestinal resections and strictures may contribute to the declining nutritional state. Emergency surgery is not often necessary and provided clinical remission is established by some means, patients then can remain well with minimal treatment for a variable period. In the collaborative study reported in this issue, ${ }^{2}$ none of the 16 patients with acute colitis caused by Crohn's disease needed emergency surgery, and only one of nine in the Leeds group had early surgery. ${ }^{3}$ High doses of steroids often produce clinical remission with diminished symptoms and disease activity, ${ }^{5}$ but as they are not always effective and patients are often in a poor nutritional state, the additional value of elemental diets and parenteral nutrition have been examined with encouraging results.

Although the initial aim was to improve nutrition during periods of active disease, investigators also gained the impression that disease activity appeared to fall and clinical remissions followed. ${ }^{7-9}$ Most of the patients were also given steroids, making it difficult to interpret the outcome in a decisive way. Controlled trials involving complex nutritional feeds alone are difficult to conduct in patients with acute disease, but this was done in a study from Northwick Park, Harrow. ${ }^{10}$ Twenty one acutely ill patients were randomised to receive either prednisolone $0.75 \mathrm{mg} / \mathrm{kg} / \mathrm{day}$, or an elemental diet (Vivonex) for four weeks. Clinical and biochemical measurements at four and 12 weeks showed similar improvements in the two groups, supporting previous uncontrolled observations. ${ }^{7-9} \mathrm{~A}$ parallel, but more radical approach has been to give total parenteral nutrition as the sole therapy to patients with severe disease..$^{11-13}$ One study of 30 patients (without controls) had three weeks' hospital treatment followed by nine weeks at home, during which time no medication or oral intake was allowed. ${ }^{14}$ Early surgery was avoided in 25 of these, who returned to work and ate normal meals without any medical support. The cumulative recurrence rate however, was $60 \%$ in the subsequent two years, which is not a particularly high figure for patients who had severe disease and were not given steroids. The policy of most clinicians would be to try and ensure the remission was maintained by steroids in patients who had severe disease.

Few patients would tolerate, or indeed need such major changes in feeding over prolonged periods and the extent to which elemental diets and parenteral nutrition are used, would be limited by cost, manpower and genuine reservations about need for anything other than very short periods in severe disease. Their potential value in producing clinical remission is worthy of note, but we should perhaps not be too surprised at this, because both treatments rest the bowel. Early surgical procedures which depended on bypassing and therefore 'resting' obstructed inflamed bowel usually improved symptoms, nutrition and disease activity. ${ }^{415-17}$ Most patients tolerate normal food, which may occasionally have to be puréed for those with strictures producing persistent symptoms of obstruction, although 
these patients usually require a surgical resection to establish a stable remission.

One can only speculate on the reasons for clinical improvement with bowel rest in Crohn's disease. On the simplest level one might expect rest to promote healing - but how? Some considerations which may be relevant include the antigenic role of food proteins and bacteria, increased permeability of the mucosa to these antigens and the patients immunological and nutritional status. Immune mediated mechanisms are implicated in Crohn's disease where cell mediated immune function is often impaired, but this may be a consequence of active disease or even malnutrition, rather than a primary phenomenon. The number of $\mathrm{T}$ cell lymphocytes in Crohn's disease increases towards normal with improvement in nutrition, which is a phenomenon also well recognised in the tropics in patients with malnutrition. Improvement in immunological function as a consequence of improved nutrition may also reduce disease activity. Many of the improvements observed in patients given elemental diets, however, have occurred early in the study before significant changes in nutrition occurred. ${ }^{1018}$ Elemental diets and exclusion surgery not only change the antigenic load from food protein but probably also modify the intestinal flora and a combination of these two factors may play a significant role in the disease. ${ }^{19}$ 20-22 Healing with a return towards normal in the gut permeability $^{23}$ may then allow reintroduction of normal diet without immediate problems. A working hypothesis along these lines has a ring of truth about it, but does nothing to explain the apparent failure of bowel rest in ulcerative colitis, which must remain an enigma.

What can one say about diets which exclude specific foods for individual Crohn's patients? ${ }^{24} 25$ We would like to believe in their value with sufficient conviction to embark on the involved measures required for their implementation, but have considerable reservations. The recently reported controlled trial from Cambridge ${ }^{25}$ dealt with only 20 patients and although the rate of relapse was higher in the 10 controls given a high fibre diet, nine of them had previously been on steroids compared with only five of 10 on the 'exclusion diet' and the distribution of disease was also different. Were the groups strictly comparable? We accept that food intolerance producing a variety of abdominal symptoms occurs up to four times more often than in normal controls and this is particularly true for vegetables, cereals, and dairy products. ${ }^{26}$ Most patients spontaneously tailor their diet to exclude items which offend. Whether or not a detailed series of challenge tests over several weeks would produce better long term results is a matter on which we are doubtful. With others, we would like to see more data from more centres.

University Hospital of Wales,

J RHODES AND J ROSE Cardiff

\section{References}

1 Ritchie JK, Ritchie SM, McIntyre PB, Marks CG. Management of severe acute colitis in district hospitals. $J$ R Soc Med 1984; 77: 465-71.

2 McIntyre PB, Powell-Tuck J, Wood SR, et al. Controlled trial of bowel rest in the treatment of severe acute colitis. Gut 1986; 27: 481-4. 
3 Dickinson RJ, Ashton MG, Axon ATR, Smith RC, Yeung CK, Hill GL. Controlled trial of intravenous hyperalimentation and total bowel rest as an adjunct to the routine therapy of acute colitis. Gastroenterology 1980; 79: 1199-204.

4 Truelove SC, Ellis H, Webster CU. Place of a double-barrelled ileostomy in ulcerative colitis and Crohn's disease of the colon: a preliminary report. Br Med J 1965; 1: 150-3.

5 Summers RW, Switz DM, Sessions JR Jr, et al. National Cooperative Crohn's disease study: results of drug treatment. Gastroenterology 1979; 77: 847-69.

6 Malchow H, Ewe K, Brandes JW, et al. European Cooperative Crohn's Disease Study: results of drug treatment. Gastroenterology 1984; 86: 249-66.

7 Voitk AJ, Echave V, Feller JH, Brown RA. Gurd FN. Experience with elemental diet in the treatment of inflammatory bowel disease. Is this primary therapy? Arch Surg 1973; 107: 329-33.

8 O'Moráin C, Segal AM, Levi AJ, Valman HB. Elemental diet in acute Crohn's disease. Arch Dis Child 1983; 53: 44-7.

9 O'Moráin C, Segal AM, Levi AJ. Elemental diets in treatment of acute Crohn's disease. Br Med J 1980; 281: 1173-5.

10 O'Moráin C, Segal AW, Levi AJ. Elemental diet as primary treatment of acute Crohn's disease: a controlled trial. Br Med J 1984; 288: 1859-62.

11 Vogel CM, Corwin TR, Baue AE. Intravenous hyperalimentation in the treatment of inflammatory diseases of the bowel. Arch Surg 1974; 108: 460-7.

12 Mullen JL, Hargrove WC, Dudrick SJ, Fitts WT Jr, Rosato EF. Ten years experience with intravenous hyperalimentation and inflammatory bowel disease. Ann Surg 1978; 187: 523-9.

13 Elson CO, Layden TJ, Nemchausky BA, Rosenberg JL, Rosenberg IH. An evaluation of total parenteral nutrition in the management of inflammatory bowel disease. Dig Dis Sci 1980; 25: 42-8.

14 Müller JM, Keller HW, Erasmi H, Pichlmaier H. Total parenteral nutrition as the sole therapy in Crohn's disease - a prospective study. Br J Surg 1983; 70: 40-3.

15 McIlrath DC. Diverting ileostomy or colostomy in the management of Crohn's disease of the colon. Arch Surg 1971; 103: 308-10.

16 Oberhelman HA Jr, Kohatsu S, Taylor KB, Kivel RM. Diverting ileostomy in the surgical management of Crohn's disease of the colon. Am J Surg 1968; 115: 231-9.

17 Burman JH, Thompson H, Cooke WT, Williams JA. The effects of diversion of intestinal contents on the progress of Crohn's disease of the large bowel. Gut 1971; 12: 11-15.

18 Saverymuttu S, Hodgson HJF, Chadwick VS. Controlled diet comparing prednisolone with an elemental diet plus non-absorbable antibiotics in active Crohn's disease. Gut 1985; 26: 994-8.

19 Winitz M, Adams RF, Seedman DA, Davis PN, Jayko LG, Hamilton JA. Studies in metabolic nutrition employing chemically defined diets. ii. Effects on gut microflora population. Am J Clin Nutr 1970; 23: 546-9.

20 Attebury HR, Sutter VL, Finegood SM. Effect of a partially chemically defined diet on human fecal flora. Am J Clin Nutr 1972; 25: 1391-8.

21 Crowther JS, Drasar BS, Goddard P, Hill MJ, Johnson K. The effect of chemically defined diet on the faecal flora and faecal steroid concentration. Gut 1973; 14: 790-3.

22 Boumous G, Devroede GJ. Effects of an elemental diet on human fecal flora. Gastroenterology 1974; 14: 790-3.

23 Logan RFA, Gillon J, Ferrington C, Ferguson Anne. Reduction of gastrointestinal protein loss by elemental diet in Crohn's disease of the small bowel. Gut 1981; 22: 383-7.

24 Workman EM, Jones VA, Wilson AJ, Hunter JO. Diet in the management of Crohn's disease. Human Nutr: Applied Nutr 1984; 38A: 469-73.

25 Jones VA, Workman E, Freeman AH, Dickinson RJ, Wilson AJ, Hunter JO. Crohn's disease: maintenance of remission by diet. Lancet 1985; 2: 177-80.

26 Mayberry JF, Rhodes J. Crohn's disease: careful attention to diet pays off. Mod Med 1979; 24: 21-5. 